\title{
THE VALUE OF ONLINE LEARNING: PERSPECTIVES FROM THE UNIVERSITY OF ILLINOIS AT SPRINGFIELD
}

\author{
Burks Oakley II \\ Director, University of Illinois Online
}

\begin{abstract}
The value of online learning is analyzed from the perspective of the University of Illinois at Springfield (UIS). The first type of value (merit, worth) of online learning is discussed, with the conclusion that online learning is of significant value to various constituencies, including students, faculty, the institution, and society. A second type of value (cost-benefit) of online learning is analyzed and seen to be outstanding at UIS, compared to other online alternatives. Finally, the two types of value of online learning are related to the Sloan-C quality pillars.
\end{abstract}

\section{KEY WORDS}

Online learning, quality pillars, cost-benefit

\section{INTRODUCTION}

Since the release of the first graphical web browser, Mosaic, by the University of Illinois in 1993 [1], the Internet has grown exponentially, permitting new and rapid access to information and improved interpersonal communication. Building upon the Internet, online courses and degrees developed using the concepts and principles of asynchronous learning networks (ALN) have fundamentally altered the face of higher education in America, specifically in the area of distance education and lifelong learning. In just a few short years, ALN has become the predominant distance education medium, quickly outpacing and replacing all other delivery modes [2, 3].

A recent review of statewide online initiatives showed that Illinois ranks first in the nation in online enrollments on a per capita basis [4]. The latest report from the Illinois Virtual Campus found that there were more than 50,000 enrollments in over 3,700 online courses offered by Illinois colleges and universities during the Fall 2003 semester [5]. In this same report, the University of Illinois at Springfield (UIS) ranked number one in enrollment in for-credit online courses of all public four-year institutions in the state.

Since offering its first online class in the Fall 1998 semester, UIS has developed online baccalaureate degree completion programs in English, History, Computer Science, and Liberal Studies, an online master of science degree in Management Information Systems, and an online master of arts degree in education (Master Teaching and Leadership, MTL) targeted to in-service $\mathrm{K}-12$ teachers. The enrollment in these programs has grown steadily: the Liberal Studies online program enrolled its first students in 1999, and now has 229 online majors and is the second-largest major in the College of Liberal Arts and Sciences (CLAS); the MTL program currently has an enrollment of 220 (this degree, which was first offered in the Fall 2000 semester, is only available in an online format). 
During the Spring 2004 semester at UIS, almost one in three students took at least one online course and one in six students took online courses exclusively. More than one-third of UIS faculty (and more than half of the faculty in CLAS) now has experience teaching an online course. The UIS campus has developed an infrastructure to serve online students, covering areas from technology to student advising. Retention in online classes at UIS in recent semesters has averaged greater than 94\%, which is comparable with on-campus retention. In the Spring 2004 semester, 18\% of all course credits offered by the UIS campus were generated by online courses. In the summer of 2003, the Board of Trustees of the University of Illinois approved e-tuition for the UIS campus. Residents of Illinois automatically qualify for e-tuition, while out-of-state students qualify for e-tuition during a particular semester if they are enrolled in an online degree program and only take online classes that semester. For the Spring 2004 semester, e-tuition at UIS is $\$ 115.00$ per credit hour (undergraduate) and $\$ 129.50$ per credit hour (graduate) [6]. Students enrolled in online courses also pay fees amounting to \$32 per credit hour [6].

The online degrees at UIS build on the strength of CLAS, with degrees in liberal arts and sciences - not just the "low-hanging fruit" of business administration and information technology offered by so many other institutions. The campus offers the only online baccalaureate degree completion programs in traditional disciplines of any public four-year institution in the state of Illinois, and one of the few online master's degrees (MTL) in the United States that prepares in-service K-12 teachers for national master teacher certification by the National Board of Professional Teaching Standards.

The UIS campus now has been offering online courses and degrees for five years. Given this past history, as well as the expressed goal of continued expansion of the online program at UIS, it is worth addressing the concept of value related to online learning, especially at UIS. It is hoped that the lessons learned about the value of online learning at UIS can be generalized and will have broad applicability at other institutions.

The American Heritage ${ }^{\circledR}$ Dictionary of the English Language [7] offers several definitions for the word "value", including:

1. Worth in usefulness or importance to the possessor; utility or merit: the value of an education.

2. An amount, as of goods, services, or money, considered to be a fair and suitable equivalent for something else; a fair price or return.

Both of these definitions - (1) the importance of the online learning experience to an individual or entity (termed "Type I" in this paper), and (2) the perceived fair price of an online education (termed "Type II" in this paper) - are worth considering within the context of online learning. The following sections analyze the value of online learning at UIS in light of these two definitions.

\section{THE VALUE OF ONLINE LEARNING TO VARIOUS STAKEHOLDERS}

It is natural to think first of the Type I value (merit, worth) that online learning has to students enrolled in online degree programs. But there also is value in online learning to a number of other stakeholders faculty, on-campus students, the institution, and society.

Value to New (Distant) Students: Online courses and degree programs make it possible for students to earn a degree from any location in the world from which they have reliable access to the Internet. Online 
degree programs have become especially popular among non-traditional students, such as returning adult students who have full-time jobs and family responsibilities. For many of these individuals, online programs provide their only chance to earn a college degree. In fact, online courses have provided a population of single working parents access to educational opportunities that they have never previously had. The value of online learning to these groups of new learners is obvious: access to quality online degree programs that will not only provide credentials and knowledge needed to advance their careers, but also will give them a strong sense of accomplishment, personal satisfaction, and life enrichment.

I cannot express in words how I feel about being an online learner at UIS. I love UIS and praise it often. Other single mothers and I chat in classes and agree that the atmosphere of learning online is wonderful. You are able to learn not only from the course experience but from other learners in other states, and you all come together for the same goal - to learn. I work full-time, and I am a divorced mother with sole custody of a 2-1/2 yr. old, 24 hours a day, 7 days a week. I made the Dean's List last semester taking 10 semester hours. There is something to be said about the quality of UIS and the courses and professors, because even when I was single and attended classes, I could not do this!

Leigh P. George, New Albany, MS

UIS Online Student, Liberal Studies

Value to Faculty: Faculty who teach online realize a number of direct benefits. One of the most important benefits is that they devote time to learning about online education, through seminars, workshops, and informal discussions. They report that this study of the teaching and learning process improves their classroom teaching and their student teaching evaluations. Many UIS faculty enroll in online professional development courses in the area of online teaching and learning offered by the Illinois Online Network (ION) [8, 9], and a number of these faculty go on to earn ION's Master Online Teacher certificate [10]. Faculty develop approaches to online teaching that are more student-centered than traditional lecture courses have been. Faculty teaching online also become comfortable using computers and Internet technologies, gaining skills that are invaluable to possess in the first decade of the new millennium. Faculty then carry these new approaches to student-centered learning and effective use of Internet technologies over into their on-campus teaching. As an example, during the Spring 2004 semester at UIS, approximately two-thirds of the courses that had accounts in Blackboard (the course management system used at UIS) were on-campus classes. Another benefit to faculty is that they often interact more closely with the students in their online classes, getting to know the students better. This increased level of interaction is reported to be a factor in faculty returning semester after semester to teach additional courses online [11]. Faculty at UIS who teach online interact with a broader range of students (not just those in central Illinois); these students bring new and interesting perspectives to the online classroom. Finally, UIS is an institution that encourages faculty to become involved in the scholarship of teaching [12], and UIS faculty are finding that data obtained from their online teaching gives them additional opportunities to present at conferences and to publish in peer-reviewed journals.

Online teaching has given me the opportunity to impact, and be impacted by, a diversity of students that I would never have in a traditional classroom. The interaction and learning that occurs in my online courses continually uplifts me and makes me glad I am a teacher.

Elizabeth Saunders

Adjunct Faculty, UIS 
Your e-mail note prompted me to think about where I find value in teaching online, from a faculty perspective. I truly believe that I get to know a higher percentage of my students better in the online format. I find that students communicate more freely. I also appreciate that I don't have to repeat the same lecture again and again; rather I can focus on the true learning aspects of interaction with students. But, I suppose most important for me is that I feel that I am reaching students who otherwise could not or would not complete their degrees or pursue a graduate education. Just this morning, I received an email from a very sharp student - the technology director at an urban library in the Chicago area. His experience in my "Emerging Technologies" class was his first exposure to a seminar. He was energized by pursuing research and sharing literature critiques and research with others in the class. It is there, in the excitement of bringing something new to these students, that I find a special personal satisfaction, value of the first type, in teaching online.

\section{Raymond E. Schroeder \\ Professor Emeritus, UIS}

Value to Existing Students: Another constituency that derives benefit from an institution's online program is on-campus students. As faculty teach online, they think more about the overall learning process, their approaches become more student-centered, and they make effective use of educational technologies. They then carry their new approaches into the classroom, benefiting their on-campus students. In addition, when an institution makes its student support services available to online (distance) students, the on-campus students quickly move to make use of these more convenient services. Finally, at UIS, a number of part-time commuter students mix online and on-campus courses during the same semester. While they may only have the time in their busy lives to take one course on-campus, the "anytime-anyplace" convenience of online courses allows them to take an online class in addition to an on-campus class, thus enabling more rapid progress towards their degrees.

Value to the Institution: An institution offering online degree programs can attract new students, thus increasing enrollment and tuition income. For reasons outlined above, institutions also can better serve existing students. In the case of UIS, the development of online degree programs and e-tuition has enabled the institution to progress from a regional campus, which served a limited number of residential students and commuter students living within a thirty mile radius of Springfield, to an institution with a national perspective and reputation, enrolling students from across the United States and indeed from other countries around the world. To advance this transformation, UIS has developed partnership agreements with community colleges throughout the country with strong online programs. This effort has boosted the campus' national visibility while attracting students who already have experience with online education [13]. The increased tuition revenue from the online program has enabled the campus to hire additional tenure-track faculty in key areas, with the added advantage that the campus can offer a more diverse set of electives on-campus and online as new faculty bring in new specialties. Finally, since UIS was founded (as Sangamon State University, SSU) with a mission of offering baccalaureate degree completion and selected master's degrees, the online program expands the ability of the campus to deliver on its core mission.

As far as the value to us, there are several points to emphasize. First, UIS/SSU has always lived on its ability to serve the "non-traditional" student. Night courses, weekend courses, Peoria courses, TV courses and the like have made up the majority of our credit generation since day one. Online courses are a logical and necessary extension of those efforts to provide access to the "non-traditional" student. We need to be doing these 
things in order to stay in touch with our primary clientele.

While we have lost many faculty lines [due to budget cuts in the past few years], we also have hired new faculty with a wide range of specializations. These hires have been possible because enrollment in the college has risen dramatically in recent years. The 200 online majors and the 200 or so Capital Scholars [freshman and sophomores] account for that growth. The online initiatives make it realistic to add a philosophy major, for example, or to grow smaller programs such as mathematics to ensure their future viability. The resulting growth in majors and enrollments in many programs gives them additional faculty lines to cover critical curricular needs that have existed for much of our history.

\author{
Bill Bloemer, Dean \\ College of Liberal Arts and Sciences, UIS
}

Value to Society: Society as a whole benefits from the non-monetary effects of higher education, independent of the delivery mode by which a college degree is earned. College graduates are more likely to vote, to have regular health care, to raise healthier children, to volunteer, and to raise children with higher measures of educational achievement. Overall, there is a strong relationship between having a college degree and measures of health, community involvement, and cultural participation, all of which have value (Type I) to society [14]. Society also benefits directly from the monetary effects of higher education, since college graduates earn and spend more, and pay more taxes than those without college degrees.

\title{
III. THE VALUE OF ONLINE LEARNING AT UIS
}

Why is the online program at UIS growing so rapidly? One answer is that students perceive the online learning experience to be a good value for their tuition dollars (Type II, cost-benefit).

Fathom, an online venture created by Columbia University in 2000 to offer digital content from Columbia and thirteen other academic and cultural institutions, failed partially because potential students did not want to pay a relatively high price for the Fathom product. "Fathom failed to persuade people to pay for what they thought they could get free in other forms" [15]. One can assume that the perception by potential students was that Fathom was not a good value for the money. On the other hand, UIS is viewed by online students as a great value. The cost (tuition and fees) of online courses at UIS is one of the lowest of any public institution in the U.S.A., and much less than that of a private institution. Also, Fathom chose not to capitalize on the nationally recognized and respected brand names of its providers. Name recognition and the reputation of the University of Illinois make the UIS online programs an especially attractive choice for students who care about quality.

In the past few years, the UIS campus administration realized that the existing policy for out-of-state tuition (essentially three-times the in-state rate) was making it very difficult to attract out-of-state students. Despite the high quality of the online programs, it is likely that the high tuition caused potential students from outside of Illinois to perceive these programs as not a very good value (Type II). However, the new e-tuition rate for UIS implemented in the Fall 2003 semester changes this perception completely. Out-of-state students are now finding UIS and enrolling in online degree programs, simply because the programs are now of such high value. The campus administration expects to see significantly increased enrollments by out-of-state students, leading to economies of scale for the entire online program. 
As mentioned in Section I, e-tuition at UIS is \$115.00 per credit hour (undergraduate) and \$129.50 per credit hour (graduate) for the Spring 2004 semester. By comparison, tuition for online programs at other institutions is much more:

$$
\begin{aligned}
& \text { University of Phoenix (undergraduate) - } \$ 440 / \text { credit hour } \\
& \text { University of Phoenix (graduate) - \$545/credit hour } \\
& \text { Franklin University - } \$ 224 / \text { credit hour } \\
& \text { Capella University - } \$ 319 / \text { credit hour }
\end{aligned}
$$

Within Illinois, several universities offer online baccalaureate degree completion programs, with tuition ranging from \$130.50/credit hour at Western Illinois University to \$348 per credit hour at DePaul University to $\$ 500 /$ credit hour at the University of St. Francis. At the graduate level, a number of universities in Illinois have online programs, but again, the tuition costs are much more than at UIS; for example, \$451/credit hour at National-Louis University and \$280-\$590/credit hour at the University of Illinois at Urbana-Champaign.

In choosing to complete the online courses and degree programs, students do make value judgments for both personal and monetary reasons. I recall students saying that, in comparison to other schools, UIS was a good dollar value. UIS tuition is very affordable in comparison to what some other 4-year institutions are charging students. Students are able to complete a 4-hour course for less than $\$ 600$. At other institutions, a similar course offering is about $\$ 1,000$. Students also chose the online degree program because they would get a degree from the University of Illinois.

\author{
Gail Taylor \\ UIS Graduate \\ B.A., Liberal Studies, 2000
}

\title{
IV. RELATIONSHIP TO THE QUALITY PILLARS
}

Mayadas first used the metaphor of the "five pillars" that support quality in online education [16]. The five pillars are learning effectiveness, access, student satisfaction, faculty satisfaction, and cost effectiveness. The Sloan Consortium has adopted these five pillars as part of its quality framework [17, 18]. It is worth examining the pillars in light of the two types of value of online learning described above.

Learning Effectiveness: Students now realize that online learning can be as effective as classroombased learning (or, for some, more effective), and thus online learning has the same or greater value (type I; merit, worth) for them as classroom learning. Online students view their degrees to be completely equivalent to degrees earned on-campus - and perhaps more valuable, since earning degrees online demonstrates that they have the drive and determination to do all this from a distance, while gaining new knowledge about the Internet and collaboration.

I would not be receiving my BA in December 2003 if it were not for the online learning classes made available at UIS. I love the classes and have learned so much. One thing that makes me angry is people will comment that online learning is so easy. I disagree totally! I have found that you must be very dedicated, organized, and motivated to do 
online learning and it is not for everyone. I have worked much harder in my online classes than I ever did in the classroom. I have also found that I am able to listen to others before voicing my opinions so quickly, because being in online classes you have time to think about what others are posting before responding, and you try to think about their views even if they are different from yours. I think that is a great quality to learn to listen to others' views. I have worked very hard in my classes and it can be very time consuming but it is worth it to me to be able to learn from my home when it is convenient!

\title{
Mary Jo Jannsen \\ UIS Student, Liberal Studies
}

Access: Many online students today would not be enrolled in degree programs if these programs were not available online. These online programs make it possible for place-bound and time-restricted individuals to work towards a degree. Distant students not only have access to online courses and degrees, they also have online access to a wide range of student support services (advising, library, help desk, etc.). The implementation of e-tuition at UIS has certainly given students throughout the nation new access to affordable online degree programs. Thus, the access pillar can be seen as both Type I value (the merit or worth of being able to complete a degree in an anytime-anyplace format) and Type II value (a fair price for the good or service).

I could write pages why online learning is so important to me. I work full-time and have 3 children and 2 granddaughters, plus I live 30 miles from Springfield. It took me 8 years to get my Associate's Degree by attending classes on campus at Lincoln Land Community College at night. I was so tired and ready to go home to be with my family but instead I went to school. After I finally got my Associate's I decided that my family was more important and I should be happy with that and decided no more school. Then, 5 years later, I decided I wanted to get my BA and took one class on campus. I was miserable and I made it through the class but decided I was too old and too tired to go 2 nights a week for 8 more years so I was going to be done. Then a classmate told me about the online program at UIS. I called the next day and talked to Sharon Chanley [UIS faculty member]. She convinced me over the telephone that online learning was for me and that I should at least give it a try. She talked me into taking two online classes (one to plan and map out my degree proposal and one to get credits for prior learning). I did it and loved it! I must be honest - in the beginning I was scared to death. I work on computers at my job but had no idea how to use search engines and do research online. I loved the two classes I took with Sharon Chanley and she was also my advisor. One of the most encouraging and motivated professors I had ever had. Since then, I took at least 8 hours and sometimes 12 hours a semester and I will graduate in December 2003 with a BA in Liberal Studies with a focus on Aging and Gerontology. My dream of getting my BA will actually be a reality!

\author{
Mary Jo Janssen \\ UIS Student, Liberal Studies
}

Student Satisfaction: Students are enrolling in online courses, semester after semester. They are telling their friends about the quality of online learning at UIS. They are very pleased with what they are learning and they are also pleased with the student support services to which they have access. As with 
the access pillar, the student satisfaction pillar really addresses both types of value: the intrinsic worth of the knowledge to individual students and the reasonable price of the online courses.

As a lifelong resident of central Illinois, my heart belongs to the University of Illinois. As a young girl, I did not have the confidence to achieve the goal of a UI education. It was a dream I never thought possible. However, I did complete an Associate's degree from Parkland College in Liberal Arts.

As my life choices were made, I constantly felt a void for not completing a bachelor's degree at UI. Even though I had a successful sales career, I did not feel complete. When I became a single mom, I realized the education was necessary.

In 1998, I saw information about online education and began to investigate how it worked. I researched and took a few initial online courses at a private college. However, when I heard about UI offering a bachelor's degree online, I immediately made the contact. Fortunately, the telephone call to Andy Egizi [advisor in CLAS Online office] was the right decision! I will graduate in Spring 2004 with my degree from the University of Illinois!

Why UI? It is very simple - the people! From the initial call to every faculty and staff member at UIS, my experience has been fantastic! I can name many individuals who have worked patiently with me to achieve my goal. There is a spirit of unity and family woven through the program. Not only are these team members professional, they are devoted to building and promoting the program. There is no prejudice, jealousy or egotism among them. They respect each other and this bond is evident to all. They do not try to pull the spotlight on them personally. They know the value of their team and genuinely believe in their work.

In addition, besides the people, I believe it is a trust issue. For a single person in her mid40 's, I sought a safe haven. This may sound strange, but embarking on such a dramatic life change, I was terrified! I found this 'security' at UIS. When I submit an assignment, I know it will be treated fairly and with confidentiality.

Of course, I chose UI for its reputation and prestige. When I visualize this document hanging in my office and added to my resume, I will be so proud. Not only for my accomplishment, but for the doors it will open for me.

\section{Georgianna H. Frye}

UIS Student, Liberal Studies

Faculty Satisfaction: Faculty are finding value (Type I, merit, worth) in their online teaching. They very much enjoy getting to know their online students on a very personal level through daily interactions, and they find positive benefit in having a more diverse group of students in their online classrooms. They also are enjoying the anytime-anyplace aspects of online teaching (as online teachers often joke, being able to teach from home while wearing pajamas). 
Through online teaching, I am able to interact closely with each student and have enjoyed watching student beliefs develop and change through the challenges presented by course content, an event that cannot always be observed and subsequently nurtured for every student in the traditional setting. Although I believe that students who choose to take online courses are often more intrinsically motivated, I also suspect that the demands presented by online courses may build students' feelings of efficacy, challenge, and ultimately competence. As a result, I believe that the online educational environment offers not only convenience for students, but also the potential to present and evaluate content in a manner that enhances learning and not simply performance.

Tara Stevens (2002)

Formerly an Assistant Professor, UIS [now a faculty member at Texas Tech]

I have taught several undergraduate and graduate classes online. My students are from all over Illinois and increasingly from other states. Feedback from students has been very favorable and appreciative, especially from women who are at home raising kids, business people who travel a lot, and those who are busy and trying to juggle jobs, family and school. I am particularly pleased that if a course is well designed, it can actually be a better learning experience (due to student-student and student-teacher interaction) than on-campus classes.

\section{David O’Gorman}

Professor, UIS

Cost-Effectiveness: The American Heritage ${ }^{\circledR}$ Dictionary of the English Language dictionary defines cost-effective as "Economical in terms of the goods or services received for the money spent." [7] Thus, cost-effectiveness is another term describing Type II value as used in this analysis. Students certainly view online learning at UIS to be cost-effective, and they comment that the UIS online education is indeed affordable to them. They realize that the UIS e-tuition is a very fair price to pay to earn a degree with the University of Illinois brand name, and the financial costs of earning their degrees online are good investments in their future.

With regards to 'cost,' there is no dollar amount one can put on education. However, I have thought about the hours of time various faculty/staff have spent with me. If they had been attorneys, it would have cost a small fortune. I know it is an exceptional value for the monetary investment.

\section{Georgianna Frye}

UIS Student, Liberal Studies

\section{CONCLUSIONS}

Online learning at the University of Illinois at Springfield has been analyzed from the perspective of two types of value. Online learning is seen to be of value (Type I value, merit and worth) to distant students, on-campus students, faculty, the institution, and society. The online program at UIS is perceived by students to be an outstanding value (Type II value, cost-benefit), especially with the e-tuition rates recently implemented by the campus. The analysis of value and online learning at UIS presented in this 
paper provides strong support for the logic and reasoning behind the Sloan-C quality pillars.

\section{REFERENCES}

[Note: All Web references retrieved on 4 April 2004.]

1. http://access.ncsa.uiuc.edu/Releases/04.24.03_NCSA_Celeb.html

2. http://www.sloan.org/programs/edu_careers.shtml\#careers

3. http://nces.ed.gov/pubsearch/pubsinfo.asp?pubid=2003017

4. Mayadas, A. F. personal communication, July 2003.

5. http://www.ivc.illinois.edu/pubs/enrollment/Fall 03.html

6. http://online.uis.edu/about.html

7. http://www.gurunet.com/ Uses the American Heritage ${ }^{\circledR}$ Dictionary of the English Language, Fourth Edition, Copyright (C) 2003 by Houghton Mifflin Company.

8. http://www.ion.illinois.edu/

9. http://www.mvcr.org/

10. http://www.mvcr.org/courses/MOT.asp?textonly=false

11. http://people.uis.edu/rschr1/interaction.htm

12. http://www.uis.edu/vision/vision2.html

13. http://www.uis.edu/clas/online/clas partner.html

14. http://www.nea.org/he/heupdate/vol9no3.pdf

15. Maeroff, G. I. “Distance Learning: Ctrl, Alt, or Del?” Trusteeship, AGB 11(4): July/August 2003.

16. Mayadas, A. F. Quality Framework for Online Education, In Panitz, B., Learning on Demand, ASEE Prism. Washington, D.C.: American Society for Engineering Education, 1998.

17. http://www.sloan-c.org/effective/framework.asp

18. http://www.sloan-c.org/effective/pillarreport1.pdf

\section{ACKNOWLEDGMENTS}

The author thanks UIS Prof. Ray Schroeder for suggesting the topic of this article, Lynn Ward for editorial comments on an earlier version of the manuscript, and numerous online students for sharing their thoughts about online learning at UIS. Finally, the author thanks Dr. A. Frank Mayadas and the Alfred P. Sloan Foundation for over a decade of strong support for online initiatives at the University of Illinois.

\section{ABOUT THE AUTHOR}

Burks Oakley II is the Associate Vice President for Academic Affairs at the University of Illinois and serves as the director of University of Illinois Online. His areas of interest include distance education, outreach, and instructional technologies on all three campuses of the University of Illinois (Chicago, Springfield, and Urbana-Champaign). Through his innovative use of technology in teaching, Oakley has earned a national reputation as a practitioner and promoter of online education. In the past five years, he has given more than three hundred invited talks at national conferences and on university campuses.

Oakley received his B.S. degree from Northwestern University and his M.S. and Ph.D. degrees from the University of Michigan. He has received numerous awards for his teaching and innovative use of technology in education, including the Luckman Distinguished Undergraduate Teaching Award from UIUC in 1993, the Outstanding Teacher Award from the American Society for Engineering Education (ASEE) in 1993, the Educom Medal in 1996, the Major Educational Innovation Award from the Institute of Electrical and Electronics Engineers (IEEE) in 1996, the Meritorious Service Award from the IEEE Education Society in 1998, the IEEE Third Millennium Medal in 2000, the Achievement Award from the 
IEEE Education Society in 2002, the Engineering Alumni Society Merit Award from the University of Michigan in 2003, and the Sloan-C Award for the "Most Outstanding Achievement in Online Teaching and Learning by an Individual" in 2003. He is a Fellow of the IEEE and the ASEE, a former Vice President of ASEE, and a member of the Board of Directors of the Sloan Consortium. Contact: Burks Oakley II, 176 Henry Administration Building, University of Illinois, 506 S. Wright Street, Urbana, IL 61801. Telephone: 217-244-6465; Fax: 217-333-5040; email: oakley@uillinois.edu. 